\title{
Uberization of labor and capitalist accumulation
}

\author{
David Silva Franco ${ }^{1}$ \\ DeISE LUIZA dA SILVA FerRaZ 2 \\ ${ }^{1}$ Instituto Federal de Minas Gerais (IFMG) / Departamento de Ensino Básico, Técnico e TeCnológico, \\ RIBEIRÃO DAS NEVES - MG, BRAZIL \\ 2 Universidade Federal de Minas Gerais / Faculdade de CIÊnCIAS EConômicas, Departamento de CIÊnCIAS AdMINISTRATIVAS, \\ BELO HORIZONTE - MG, BRAZIL
}

\begin{abstract}
The development of the productive forces appropriated by capital, combined with the context of changes on sociocultural relations that encompasses the spheres of production and consumption, has enabled the rise of the phenomenon of uberization of labor, a term derived from the way the company Uber is organized. This phenomenon is usually associated with the business of so-called sharing economy, and it opens the debate to the specificities of the structuring categories of capitalist accumulation that encompass online labor relations. This article lays the theoretical basis to advocate for the following argument: the uberization of labor represents a particular capitalist accumulation, by producing a new form of mediation of the subsumption of the worker, which takes on the responsibility for the main means of production in the productive activity. Based on the Marxian theoretical contribution, a critical analysis about the phenomenon of uberization is presented, which is intrinsically related to the innovative forms of management, while it also acts to intensify the work precariousness.
\end{abstract}

Keywords: Uberization. Capitalist Accumulation. Labor Relations. Precariousness.

\section{Uberização do trabalho e acumulação capitalista}

\section{Resumo}

O avanço das forças produtivas apropriadas pelo capital, aliado ao contexto de transformação das relações socioculturais que abarcam as esferas da produção e do consumo, tem possibilitado a ascensão do fenômeno da uberização do trabalho, termo derivado da forma de organização da empresa Uber. Esse fenômeno tem sido usualmente associado aos negócios da denominada economia de compartilhamento e abre o debate acerca das especificidades das categorias estruturantes da acumulação capitalista que abarcam relações de trabalho virtualizadas. Neste artigo, buscamos lançar as bases teóricas para a defesa do seguinte argumento: a uberização do trabalho representa um modo particular de acumulação capitalista ao produzir uma nova forma de mediação da subsunção do trabalhador, o qual assume a responsabilidade pelos principais meios de produção da atividade produtiva. Partindo do aporte teórico marxiano, traçamos uma análise crítica acerca do fenômeno da uberização, que está intrinsecamente relacionado às inovadoras formas de gestão, enquanto, por outro lado, intensifica a precarização do trabalho.

Palavras-chave: Uberização. Acumulação Capitalista. Relações de Trabalho. Precarização.

\section{Uberización del trabajo y acumulación capitalista}

\section{Resumen}

El avance de las fuerzas productivas de las cuales el capital se ha apoderado, aliado al contexto de transformación de las relaciones socioculturales que abarcan las esferas de la producción y del consumo, ha posibilitado el ascenso del fenómeno de la uberización del trabajo, término derivado de la forma de organización de la empresa Uber. Este fenómeno ha sido usualmente asociado a los negocios de la denominada economía colaborativa y abre el debate en cuanto a las especificidades de las categorías estructurantes de la acumulación capitalista que abarcan relaciones de trabajo virtualizadas. En este ensayo, buscamos lanzar las bases teóricas para la defensa del siguiente argumento: la uberización del trabajo representa un modo particular de acumulación capitalista, al producir una nueva forma de mediación de la subsunción del trabajador, el cual asume la responsabilidad por los principales medios de producción de la actividad productiva. A partir del aporte teórico marxiano, trazamos un análisis crítico acerca del fenómeno de la uberización, que está intrínsecamente relacionado a las innovadoras formas de gestión, mientras que, por otro lado, intensifica la precarización del trabajo.

Palabras clave: Uberización. Acumulación Capitalista. Relaciones de trabajo. Precarización. 


\section{INTRODUCTION}

As an ontological category, labor is what differentiates human beings from other animals, and it is the determinant (and dialectically determined) element of the various aspects of social life. According to Marx, the sensible activity is the way through which individuals reproduce their existence, express their humankind, and interact with nature. "[Labor] is a necessary condition, independent of all forms of society, for the existence of the human race; it is an eternal nature-imposed necessity without which there can be no material exchanges between man and Nature, and therefore no life" (MARX, 2013, p. 98).

As Antunes points out (2000), under the capitalist system, labor is devoid of meaning since it becomes a mediated activity to produce value for the capitalist. As an expression of political-economic and cultural phenomena, the models of organization of labor are continuously transmuted to cope with the changes in the "system of social metabolism of capital," which always tends to expand (MÉSZÁROS, 2011). In this sense, labor control strategies, beyond technology innovations, invariably encompass different forms of exploiting the labor force.

The continuous development of the productive forces to carry out the valorization of value promote phenomena such as the relatively recent and worldwide observed 'uberization of labor,' a term that refers to the company 'Uber,' regarding its particular model of organization of labor. Uber has developed a digital platform available for smartphones, connecting customers to service providers. The company operates in urban transport and differs from other competitors in the segment because of elements such as affordable prices compared to conventional taxis; linking the route of the ride to the route indicated on the smartphone's GPS; offers greater control capacity over the service provider; and payment for the transportation service directly to the user's credit card. Without any employment relationship, Uber drivers work as freelancers and take risks to offer the service, holding almost all the means of production needed to carry out the activity and for which they are fully responsible. Therefore, considering that the Brazilian Labor Law does not clearly classify the driver as an employee, this worker is not only demanded to invest in their own equipment for work but is also unprotected in the labor relationship.

Inasmuch as the company no longer needs to hire the worker as an employee and does not need to invest in the majority of the physical means of production (which constitute constant capital), the surplus-value that the capitalist appropriates becomes maximized at a level unimaginable for traditional companies, which is revealed an imperative for other companies to adopt similar models of structuring their business (SRNICEK, 2017). Based on this context, this article discusses the following argument:

- The uberization of labor represents a particular form of capitalist accumulation, by producing a new form of mediation of the subsumption of the worker who takes responsibility for the main means of production of the productive activity.

The studies on uberization in Brazil are scarce (for this research we used the keyword "uberização" (Portuguese) in the search engine of the databases SPELL and SciELO, obtaining zero results). Therefore, this article attempts to clarify some aspects of this thriving phenomenon that can promote ruptures over labor relations in the national context. Without intending to appear neutral, which is often seen as an ideological resource for the maintenance of the status quo, we aim to broaden the debate about the exploitation that uberized labor relations engender and, consequently, to render more favorable the subjective conditions demanded by the collective mobilization seeking rights' improvement and expansion. It is important to note, however, that it is impossible to fully overcome these types of dissatisfactions and conflicts because the regulation of labor relations only provide a better social interaction within the framework of the capitalist system but do not overcome the contradictory capital-labor relationship.

For the transformation of the 'concrete real' into the 'thought real,' considering the mode of knowledge production of the dialectical historical materialism, this article presents an approximation of a phenomenon that is part of a wider range of mediation than we would be able to cover here. We consider this first approximation of the phenomenon is significant, paving the way for subsequent critical assessments of one of the faces of the global trend of flexibilization of labor relations. 


\section{CAPITALIST ACCUMULATION}

Following the Marxian terms, the central categories of the capitalist production process are exposed in this study in order to analyze how they are expressed in the context of uberization. The capitalist sociability is based on the antagonism of two classes, the working class and the capitalist (abstracting, for now, the sociocultural heterogeneity of the different stratifications within each of them). These classes interact and confront each other in the dynamics of the production of goods - as well as in the production of several mediations emerging from the process of human sociability under capital.

Under the capitalist system, the labor force is the worker's commodity, which they are impelled to sell to guarantee their subsistence. Like any other commodity, the value of the labor force is represented by the socially necessary labor time for its reproduction, i.e., how much the worker needs to work daily to meet the needs of the production and reproduction of the labor force, regardless whether these 'wants' spring from the stomach or from fancy (MARX, 2013). Therefore, it is the worker's responsibility to reproduce as a labor force and to produce the future labor force (that is one of the reasons Karl Marx calls the working class "proletarian class"). The capitalist, who owns the money for productive investment, is the buyer of the factors necessary for the production of goods, with the aim of obtaining a value higher than the one initially spent, as expressed in the following formula:

$$
M-C_{M P} L \ldots P \ldots C^{\prime}-M^{\prime}
$$

The capitalist's money (M) is used to buy the commodities (C) that are the factors of production, i.e., the means of production $(\mathrm{Mp})$ and the labor force $(\mathrm{L})$ - the relationship between the capital advanced in the form of $M p$ and $L$ composes what Karl Marx calls form of capital value. By using these factors in the productive capital $(P)$, new commodities are created $\left(C^{\prime}\right)$, that is, the commodity-capital that results from production. The commodity capital incorporates the value of the raw material consumed, the value of the wear and tear of the means of production not consumed in a single production cycle, the value of the labor force and the surplus-value. It is worth noting that the means of production whose value takes more than one cycle to be consumed is, for Marx (2014), fixed capital - for example, the constant capital invested in machinery and other physical structures used in several productive cycles - while those factors of production whose value is fully incorporated into the commodity in a single cycle is recognized as circulating capital - such as raw materials, which are also part of constant capital, and the labor force (or variable capital).

With the circulation and the trade of commodities, the capitalist obtains the surplus-value and money-capital $\left(\mathrm{M}^{\prime}\right)$, which must be reinvested, in part or fully, in factors of production (means of production and labor force), so that there is an effective movement of capitalist accumulation. The accumulation movement occurs because the value controlled by the capitalist, at the end of the production process, is greater than the originally advanced capital - although part of that value remains fixed as means of production.

The labor force is the only element in the production process that can generate more value than its own, so the surplus-value represents the time that the worker spends working for the capitalist's accumulation of value, not the time working to produce the value of the reproduction of their labor power. The consolidation of this form of production enabled the capitalist to have a strategic role of control over the work process and to focus on how to increase the surplus-value, be it in an absolute or relative way. This occupation is not only instrumental rationality related to greed but is also a socially conditioned need to maintain their capital, which is only possible the production is in a movement of expansion.

While the absolute surplus-value is obtained by extending the working day, the relative surplus-value derives from the reduction of socially necessary labor time used for the reproduction of the labor force. By improving methods, instruments, and the intensity of the activities in the industry (for Marx, industry is understood as the set of productive activities of capital, therefore, involves what we roughly call 'services'), the worker produces the value of their labor force in less time, and, therefore, more time of their day is used to produce surplus-value for the capitalist.

The worker operating in cooperation is a specific form of the capitalist production process, which is opposed to the process of production when conducted by independent, isolated workers, or small masters. This form is the first transformation of labor in its condition of subsumption to capital (MARX, 2013). 
Labor subsumed to capital means that productive activity is exercised on a subordinate basis so that the knowledge, mastery, and purposes of workers' roles are determined by capital. This subsumption is the result of historical processes that involve the very constitution of the labor force as such (ABÍLIO, 2011), i.e., the transformation of sensible activity into a commodity that must be sold by the worker to their subsistence.

The manufacturing industry promoted the transition from the form of 'formal subsumption' to the form of 'real subsumption' of the worker to capital, which means a new stage of alienation (MÉSZÁROS, 2016). The introduction of cooperation, as a necessary means for the movement of capital expansion, has a dual nature: while fostering the potential for the formation of a new class consciousness and a new historical understanding of labor as a social process, it also promotes the division of productive activity and greater capacity of determination by the capitalist on the way the worker acts. In this sense, Marx (2013) analyzes that the enrichment of the social productive force of the collective worker in manufacturing is conditioned by the impoverishment of the worker in his individual productive forces.

The next stage of capitalist accumulation is the development of machinery applied to the productive process. The technological evolution of the incorporation of machinery to the application of labor force has several consequences for the production environment, such as the possibility of extending the working day beyond the natural limit previously necessary for the reproduction of the labor force, less dependence of the capitalist on the knowledge of the worker, and lowering the cost of the product - considering that the production or purchase of this machinery costs less work than the work that was done by the worker to be substituted (MARX, 2013).

The machinery and the large industry brought about changes in the socio-productive environment that are still observed in the present day, such as renewal and continuous development of production technology; expansion of globally fragmented value chains; greater money flow between capitalists and rentiers in the financial market (which is contradictorily interwoven and autonomous in relation to the productive market); and the rise of the service sector as a productive industry. In book II of "Capital," Marx (2014, p. 145) points out that a commodity is not necessarily a physical object, it can also be some activity, as he illustrated in the example of the transportation industry:

But what the transport industry sells is the actual change of place itself. The useful effect produced is inseparably connected with the transport process, i.e., the production process specific to the transport industry. [...] However, the exchange value of this useful effect is still determined, like that any other commodity, by the value of the elements of production used up in it (labor power and means of production), plus the surplus-value created by the surplus-labor of the workers occupied in the transport industry.

Thus, there is the suppression of $C^{\prime}$, being the production process concomitant to the consumption process, as follows:

$$
M-C_{M p}{ }^{L} \ldots P . . . M^{\prime}
$$

In a first abstraction, when service activity is turned to the circulation of commodities (like wholesale and retailers), it contributes to capitalist accumulation by reducing the period of rotation of productive capital and reducing the amount of advanced money-capital needed for the realization of the value of the productive capitalist. These activities are discussed by Marx (2017) in Book III of "Capital," under the discussion of commercial capital. As these activities are not the object of this article, it is enough to emphasize that, in this case, there is no production of value nor surplus-value. However, in a second moment, we have to consider the new goods being produced, such as commuting, storage, entertainment; which are considered to be in the service sector. In this case, there is a labor force producing value, and there are capitalists appropriating surplus-value. Following the very trend of capital, these service industry capitalists also seek ways to increase added-value constantly.

As Marx (2013) points out, technological innovations and new forms of productive organization adopted on a large scale by productive agents tend to make the profit rate fall. Therefore, in order to recover the possibilities of surplus-value, the capitalist is forced to search uninterruptedly for new ways of overcoming the competition. As Oliveira (2003) points out, the recent trend is that the capitalist depends less and less on the capital advance for the realization of value (the moment necessary for profit to emerge). In this sense, there is the movement for the worker's compensation to occur when the sales 
of the commodities put into circulation happen, in addition to the effort to reduce the cost of the labor force. This movement encompasses the various forms of outsourcing and deregulation of the capital-labor relationship, with the reduction of certain labor rights, whose costs are part of the variable capital, and the reduction of the need to share surplus-value with the state - one example is the reform on the labor law, which occurred in Brazil in 2017.

This context provides the grounds for the next part of this study, which discusses the categories of accumulation in the face of the process of uberization of labor. After all, how can the subsumption be recognized of the worker, who apparently is not subordinate to a boss and they determine their own working days? What is the ownership of the means of production of the capitalist, in this context, if the uberized worker has the main physical resources necessary for productive activity? How is the work of a driver who provides service to Uber related to the process of capitalist accumulation? This study intends to provide argumentative analysis to elucidate these issues in the following sections.

\section{CONTEXT OF UBERIZATION OF LABOR}

From the 1970s, the development of the large industries' productive forces gradually incorporated the use of microelectronics and network connectivity to the productive system. As a result, there was a significant change in the organic composition of the capital of several companies, mainly in the industry of goods, with a reduction in employment (less investment in variable capital) and greater investment in technology equipment and machinery (more constant capital), especially those related to the computational components. In addition to the gains made by technological innovations, there is a downward movement in the cost of the value of the labor force, forcing the processes of deregulation of legal labor protections and the increase of outsourcing.

It is important to emphasize that the dissemination of computers and the Internet promoted changes not only in the production environment but in all human sociability integrated with the movement of capital. Thus, considering that the uberization process depends on the online environment of digital platforms, it is important to observe that its emergence only started after the adoption of the connectivity technology by the productive organizations, and the availability of this technology in large scale for the population (service providers and consumers).

The online environment supported by the Internet, as a movement prior to uberization, led to the crowdwork, i.e., the work of the multitude, which becomes integrated into the productive system, being able to act directly or indirectly in the process of valorization of value. Also known as crowdsourcing, in this type of work the function normally performed by a single worker (or small group of workers) becomes indefinitely decentralized. In this case, a company can turn to the crowd asking for help to perform a service, resulting in a large number of people who take responsibility for a small part of the task (HOWE, 2006). The crowdwork usually has three elements: the "petitioners," who represent the companies or the people who demand the service; the online platforms, which provide digital places to find supply and demand (and is compensated with a percentage of the amount paid to workers who engage in the task); and workers providing the service (SIGNES, 2017).

An emblematic case of crowdwork is that of Amazon, which launched the Mechanical Turk segment in 2005. Amazon Mechanical Turk is a marketplace platform that helps companies find people to perform online tasks that computers are still not able to execute perfectly, such as identifying items in a photograph, analyzing real estate documents to identify information, small product descriptions, or transcribing audio from digital files. Amazon calls them human intelligence tasks (HITs), which turns out to be ironic, as they do not require great cognitive effort from their performers. Perhaps because of this, and also because they are designed to take little time from service providers, the pay for performing these tasks is usually low - from a few cents to a few dollars (HOWE, 2006). 
However, not only tasks that require little qualification are demanded in this type of work. On the InnoCentive website, for example, some companies, such as Procter \& Gamble and Exxon, are launching challenges that are available to people around the world who want to try to solve them. If the objective is reached, the "winner" receives a prize in cash and the company launching the challenge wins the rights to the solution presented, and may even patent it if this solution is related to an innovation that can be protected. So, the area of research and development of a company can be outsourced to people who are not even recognized as their workers.

After all, what is the most visible outcome of crowdwork-type activities? Apparently, the petitioners seem to be satisfied, since they have a considerable cost reduction when comparing how much they would have to spend if they needed to hire employees to carry out the tasks. Service providers are also satisfied because such work is performed at the time defined by them and with the period of time they have established, representing only "extra money" obtained by the expenditure of time in the "vacant hours." From the point of view of the working class, however, it is important to observe that the expansion of such services can lead to a scenario in which these activities cease to be sporadic and self-determined and become the source of principal income of an expressive number of workers - without any legal protection.

Parallel to the development of the crowdwork productive activities, and from within the connectivity movement aimed at economic gains, there is the emergence of the sharing economy. This system is about sharing resources (goods or services) intermediated by an online platform, and there are similar concepts such as the collaborative economy, collaborative consumption, on-demand economy, and peer-to-peer economy.

It is not the case here to go in depth in the examination of these concepts since, although the uberized activity may be considered as part of the sharing economy, we are treating uberization as something different. It is not about sharing an object, a space or an exchange of services, but it is about the actual sale of the labor force - even though, at first sight, the uberization does not explicitly show this economic relationship. We do not even believe there is a generalized movement of sharing economy, based on cooperative values, as usually advocated in the media and even in academic research. Companies such as Airbnb (rent of private houses/rooms) and RelayRides (rent of personal cars) have become giant, highly capitalized and professionalized industries, with their so-called "sharing members" mostly made up of service providers seeking ways to make money - and investors demand for the business model of these companies to have a good return, as pointed out by Slee (2017).

Thus, in the context of smartphones applications with wide access to the population and organizations entering the crowdwork system, the company Uber appeared in the USA, in the city of San Francisco, in 2008. The idea behind Uber seems to be very simple: in cities, some people have the time available to work as freelance drivers (either because they are unemployed or because they want to supplement their income beyond the main occupation) and there are potential passengers. Anyone who needs to travel around the city analyzes the available options. Choosing the Uber service, with few touches on the smartphone the driver appears and leaves the applicant in the destination ordered. The payment is written off on the credit card registered by the customer, and the driver receives the amount, discounted the fee charged by Uber. With this "simple" business model Uber has reached in 2017 a market value of 70 billion dollars (SLEE, 2017).

The next section will present in depth the different aspects related to this type of labor, leaving behind the simplistic business description offered above. We will advocate that the uberization is a form of capitalist accumulation and worker subsumption. Although uberization is not restricted to the activity of the company Uber, the study focuses on this specific organization, not because it is the one that gives the name to the phenomenon, but because of its global reach and greater availability of studies about the company's performance. 


\section{THE MOVEMENT OF CAPITALIST ACCUMULATION OF THE UBERIZED LABOR}

In a scenario of fewer job positions, of productive activities that do not guarantee a satisfactory compensation, the sale of the labor force through applications should be considered not only as a worker's option but also as a result of the socioeconomic context that leads to these kinds of options. Considering the production restructuring, Oliveira (2003) points out that wages, recognized as variable capital, turned to be considered as a "cost" for the capitalist. However, when the remuneration of the worker becomes dependent on the realization of the value of products-commodities, it ceases to be a cost of advancement of capital, and its existence is conditioned to the effective realization of the value.

The group of workers is transformed into an indeterminate sum of active and reserve military personnel, which are exchanged not in business cycles but daily. [...] This is due the fact that the jobs positions cannot be fixed, that workers cannot have labor contracts, and that the rules of Welfare have become obstacles to the achievement of value and profit, since they persist in considering the wages - and the indirect wages - as an advancement of capital and a capital "cost" (OLIVEIRA, 2003, p. 136).

In the case of the company Uber, the worker has to have the car, the cell phone and all the main physical means to carry out the activity. So why do the capitalists of Uber have the realization of surplus-value? To discuss this issue, it is worth remembering that, as a commodity, the labor force has use-value. In the context of the great Toyotist industry, the worker, in order to maintain the use-value of their labor force commodity, is led to adopt a position of greater creativity, "investment" in themself for continuous training, technological updating and emotional connection to the productive organization. When considering the new context of Uber, the worker must "invest" in the equipment and machinery necessary to carry out the work of transporting passengers, presenting a sellable labor force. This equipment, therefore, instead of the constant capital of the capitalist to carry out the transport activity, becomes necessary so that the worker can continue to pursue their own maintenance. The fact that the workday is not previously fixed does not, therefore, remove the capitalist's role as the buyer of the labor force, nor the worker's role as the seller of the labor force, since what changes, in this case, is the need for capital advanced by the capitalist. Marx (2013) states that 'pay per piece' is the ultimate form of remuneration for capitalism. Uber now presents the 'pay per ride.'

In book II of "Capital", Marx (2014) discusses the changes in the capital's rotation time and the amount of capital to be advanced by the capitalist - due to the differences between fixed capital (means of production that keeps part of its value during the production process) and circulating capital (means of production whose value is integrally incorporated in the commodity produced within the same productive cycle). In an industry based on uberized labor relations, the value needed to purchase the means of production is divided between capitalist and worker. The capitalist advances its capital in the acquisition of digital means of production, which involves both fixed capital and working capital. As for the workers, they need to have the means of production linked to the service delivered outside the digital environment. The means of production that would be capital advanced by the capitalist to be materialized, for example, in a fleet of cars, it is no longer necessary to be disbursed. Not even the maintenance of the means of production of non-digital labor needs to be considered in the capital advanced by the capitalist since the worker is responsible for this.

According to Marx (2014), the time it takes for fixed capital to complete its cycle is the time that corresponds to the capitalist's demand for a new capital advance, i.e., for the acquisition of durable means of production. During this time, therefore, the capitalist 'treasures' surplus-value to put it back into the production cycle at the appropriate time (at this point there is a key role played by the financial market, which is an object for discussion for a future study). However, in the industrial sector based on uberized relations, when the means of production belonging to the worker loses its use-value, the capitalist will not need to reinvest in fixed capital, and can only disconnect the worker from the platform, which is ensured by the application's evaluation mechanism.

What are the means of production needed by the capitalist of Uber, therefore, to assure the subsumption of the driver's labor? The answer to this question is the digital platform itself, owned by the capitalist, which is necessary for the worker to use their labor force. For the construction of the platform and its availability in a wide geographic environment, Uber had to invest (and attracted financial market investments for this purpose) in developing/improving its technology, the financial 
management, and marketing actions - market research, advertising, price discounts. This required the purchase of labor force directly connected to technology, finance, and marketing sectors.

As the company strives for the platform to become widespread among consumers and service providers, it focuses on the management of the work through the application (which already has some competitors) and has great control power over the worker performing the service. In this labor relation, the fact that the workers own the means of production does not make them less subsumed, and may, in fact, mean the opposite: even greater subsumption, in a scenario of structural subordination (CHAVES JUNIOR, MENDES and OLIVEIRA, 2017). The reason for this is the high unemployment and the increasing number of precarious job positions, together with the absence of prospects for better occupation. The worker subjected to this restrictive context finds in the offer of Uber a viable option to sell their labor force. Uberization reinforces the maximum degree of influence of industrial capital (detained by Uber) on the labor process subsumed to capital - in this case, in a sort of online subsumption (a new form of mediation of real subsumption to capital):

Industrial capital is the only mode of existence of capital in which not only the appropriation of surplusvalue or surplus product but also its creation is a function of capital. It thus requires production to be capitalist in character; its existence includes that of the class antagonism between capitalists and wage laborers. To the degree that it takes hold of production, the technique and social organization of the labor process are revolutionized, and the economic-historical type of society along with these salaried workers (MARX, 2014, p. 146).

In the labor process under the uberization mode, the physical elements of the cost of production that are needed to develop the productive activity are transferred/outsourced to the drivers - thus, they are part of the reproduction value of their labor force. Uber, however, does not necessarily pay the necessary value for the reproduction of the worker, besides remunerating only when the service is provided - which, if it does not occur, will not exempt the worker from paying the costs of maintaining the vehicle, for example. The commodity-product (the passenger transportation) can thus present a surplus-value that becomes potentialized by the mitigation of the constant capital needed by the capitalist, which reflects in the rate of profit of the sector (in Karl Marx, the rate of profit is the relation between the surplus-value produced and the total capital invested by the capitalist).

In this new mediation of the real subsumption, which we consider the online subsumption of labor to capital, the workers are controlled and driven - both subtly and ostensibly - to increase productivity. The activity of the drivers themselves is highly individualizing. However, it is important to consider them as part of a collective work that is fundamental to the practices of promotion, management, and distribution of the commodity-product by the company (transportation). It is a type of cooperation that is managed by the company seeking to distribute drivers in the areas of greatest demand. Taken together, drivers act as gears necessary for the production of the urban transport service - except that, in this case, the machinery that puts the gears to work is, for the most part, acquired by the workers, leaving the capitalist with the control of pressing the digital "button" that makes the machinery to work. In the next section, we explain the management and control practices adopted in this business.

\section{THE SUBSUMPTION OF THE WORKER FROM THE MANAGEMENT MODEL OF UBER}

The authors in the field of administration in Brazil, in general, have not yet elaborated in depth on the particularities regarding the management strategies and practices of companies that manage their labor force entirely at a distance, especially when it comes to workers without formal work contracts, like Uber drivers. The intention in this section is to present some of these practices already observed in the academic literature, to better understand them and to reinforce our argument of subsumption of the worker, who is under pressure not only from the organization of labor but also from the socioeconomic context of competition and unemployment.

According to Slee (2017), Uber has increased the number of drivers from 10,000 to 150,000 in two years (2013 to 2015). Such expansion was facilitated by the large inflows of venture capital funds over time. The funds raised in the financial market strongly contributed to the company's expansion strategies. In the cities where it is in the initial stage of business, it is common that 
Uber offers benefits for customers (discounts and free rides) and to drivers (gratuities, attractive remuneration, bonuses when recommending the opportunity to new drivers). As Uber consolidates its position with customers and drivers and the business is stable in the new city, the consistent trend is that the drivers' compensation is reduced (the price paid per kilometer reduces and/or there is an increase in the percentage of the ride retained by the company), and discounts reduce as well (SLEE, 2017).

Application drivers are responsible for the costs of updating their driving license $(\mathrm{CNH})$, to be legally authorized to work as a driver, as well as for the costs related to the service per se, such as car, fuel, insurance, maintenance of the vehicle and other expenses to please the customers (water and candy). To attract new drivers, the company's advertisements bring discursive strategies that reinforce social values focused on the characteristics usually attributed to entrepreneurs, such as not having a boss, freedom to establish the working hours, progressive gains and adventure getting to know the city. With the strategy of recommending new drivers (in a kind of pyramid scheme), Uber creates ways for the driver to seek competitors for themselves.

Following the patterns of crowdwork, the drivers have virtually no personal contact with representatives of Uber, which, in fact, can be a differential. The company becomes an option for workers that seek occupation and have difficulty entering the formal labor market:

It is not the curriculum, the dynamics guided by the human resources, the candidates' appearance, "emotional intelligence" - among other publicly unmeasurable factors that nowadays mediate entry and exit from the labor market - that defines the achievements of the crowd [work]. Indiscretion is the starting point [...]. Its formulation makes explicit a relation between a new people management and the accumulation of capital. A type of management that takes place in the dispersion, in the absence of definitions and measures (ABÍLIO, 2011, p. 205-206).

The algorithms - which characterize the method used to perform a calculation, mainly used for automated decisions - shows a vision of impartiality. However, they are easily manipulated to direct drivers to the actions desired by the company (PASQUALE, 2015). The declared function of the "dynamic fare" of the company, for example, is used to control the supply and demand of customers and drivers. If the "admission" of the worker has few criteria and poses fewer barriers, the maintenance in the system to provide the service is the opposite. In managing the activities, Uber uses algorithms to seek personalized incentives for drivers and to distribute them to areas of greater or lesser demand in cities. Uber distributes the commodity-product by showing drivers the areas where prices are highest, in an indirect driving strategy. On the other hand, it is not possible for the client and the worker to know the exact calculation formula:

About the dynamic fare, the general manager explained that the dynamic price was activated by an algorithm, and "the maximum price and the average amount practiced in the city" determined by the managers. However, the operations manager reported that one of their functions was to turn off this system in exceptional cases, for example, on the day of the taxi drivers' demonstrations, to avoid making the price more expensive. These data point out that the price charged is not directly related to demand, once again distancing Uber's business model from the collaborative economy (LEME, 2017, p. 84).

The collective worker framed by Uber is fundamental for its success, improving the corporate image based on the satisfaction of the customer, who has a fast service, at an affordable price, with controlled trajectory and easy payment. In Brazil, from the amount paid by the customer to the platform, the company deducts a percentage from the fare of the driver, $25 \%$ in the UberX category (the most common) and $20 \%$ in the UberBlack category (higher standard and new cars). Considering the Uber's unilateral decision on how and how much to charge the customer (currently the driver no longer has access to ride price information, from which this percentage is calculated), there are cases where the remuneration earned by the driver barely covers all of their costs, especially when taking into account that many drivers finance a car to be able to carry out the activity - if they are disconnected from the platform, they have the cost of paying for the vehicle, lose that source of income and have no labor and social security rights guaranteed:

If the pay is really so low, why do so many people drive with Uber? For those who have a car, driving for Uber is a way to convert this capital into money; some underestimate the costs of driving full time; for some, flexibility is an advantage, for others, driving with Uber offers the same as being a taxi driver offered for many years - a job that requires little skill, and that has low start-up costs, is better than 
staying at home without doing anything. Moreover, as Uber reduced the demand for taxis in many cities, taxi drivers' income reduced, which made Uber the best option for drivers (SLEE, 2017, p. 119).

One observation regarding Slee's (2017) study is that the driver does not have capital but labor force and working instruments. The car, for example, is a mass of means of production, but it is not an expression of value to be valued for the worker. In order to manage this labor force and increase worker productivity, Uber's practices are even more sophisticated. According to the New York Times report (SCHEIBER, 2017), considering that the company cannot request driver productivity directly (since drivers are not employees), Uber uses methods of psychological manipulation through its algorithms. Before completing a ride, the driver already receives the call to accept the next ride, so that this reverts to an almost euphoria for more money. In addition, in order to keep drivers active, the company has exploited the tendency of some people to set personal goals, so when the driver presses the button to disconnect from the application, they receive an alert from Uber that they are close to reaching their goal - which often makes them change their mind and continue working. Thus, it is possible to see the use of Uber's machinery (software integrated with the cell phone) used to increase the absolute value (expansion of the working day) and relative (as it reduces the value of the labor force, with the increase in the number of drivers) and reduction of the remuneration in spite of the effective reduction of the value of the labor force.

There are also more explicit control methods. If the driver rejects many rides, they may be suspended or disconnected from the platform. The application registers the customers, the evaluations they carried out, the criticisms, the routes covered, the times and even if the driver drove properly in traffic. Drivers must follow a series of standards set by the company, such as not prioritizing customer service, not passing personal numbers on to customers for private rides, non-publicizing other applications and the obligation to follow the price of the ride determined by the application. The supervisor of the driver's performance, instead of someone hired by the company, is the customer. As the service is a commodity consumed concomitantly to its production, there is no one better than the customer to evaluate the provider. According to the Uber website:

IDEALLY, you should keep an excellent service to your passengers on all rides, turning on the air conditioning, offering candy and water and especially keeping a clean car, vacuumed from the inside. That way you will, without a doubt, be able to KEEP YOUR GRADE ABOVE 4.6 (UBER, 2018, emphasis added).

Thus, with a maximum of 5 stars in the evaluation of each customer, the driver must maintain at least the average rating of 4.6. If the driver is not able to maintain this performance (which also depends on the subjectivity of the customer who evaluates them), the driver may be temporarily suspended or even instantly disconnected from the platform without any notice from Uber. The evaluation system also reinforces the valorization of managerialism by society (GAULEJAC, 2007), which is no longer limited to the formal labor market and outsources part of the control activity to the consumer. Thus, the worker is autonomous, but it is the company that defines the goal and punishes them if the goal is not achieved. This situation does not, therefore, support the common discourse that attributes to the uberized worker the status of being their "own boss":

The grade - or evaluation - has a clear characteristic of a control tool when it is verified that the main user of the evaluation is Uber, not the customers since it is not possible for the customer to choose a driver for their grade. The Uber algorithm selects and forwards, without giving a choice, the driver that is closest to the client. Here Uber moves away from other platforms like Mercado Livre, eBay, and even Airbnb: in the applications of these companies, both the customer and the sellers choose each other, and the grade is used as a criterion to guide the choices. With Uber, both client and driver are automatically interconnected (CARELLI, 2017, p. 143).

In Uber's management model it is possible to observe that the control is cleverly practiced by the company. If the driver owns most of the means of production to perform the work, then it is clear that, in the uberized work, the digital platform is the means of production that characterizes the subsumption of the worker in this type of activity. Drivers must maintain a unilaterally defined performance standard and are encouraged to produce and create as much value as possible (the worker produces value by producing the equivalent of the value of their labor force and creates value by producing 
surplus-value). In an environment of flexible working relationships, this scenario demonstrates that, due to the correlation of asymmetric forces, the worker is the one to cope with the flexibility and the risk. The company is already protected by labor and risk liabilities with most of what would be constant capital, even if it can earn up to $25 \%$ of the income of the worker who provides the services.

\section{FINAL CONSIDERATIONS - THE TRENDS TOWARD THE UBERIZATION OF LABOR}

The discussions on this phenomenon are just starting. In this article we advocate that the uberization of labor represents a particular form of capitalist accumulation, producing a new form of mediation of the subsumption of the worker, who takes on the responsibility for the main means of production to perform the labor activity. The online subsumption of labor to capital indicates that the worker is subordinate to the labor relationship under the uberization pattern, although the immediate appearance is of autonomy and freedom over the production. The determination on how to execute the work, on the standards and the productive goals is centralized by the company that owns the intermediation platform, while the worker is not submitted directly to a formal work contract but is subject to the requirements established by the company, running the risk of being disconnected of the system and unable to work. The scenario of structural subordination reinforces the need of selling the labor force in exchange for self-subsistence.

In the context of uberization of labor, while the United States is the cradle of this socio-productive technology, the range of activities following this model in the world is increasing, especially in emerging countries. In Brazil, there is already a trend towards migration and/or creation of several productive activities that adopt this form of work. As for Uber, there are about 500 thousand drivers registered, according to the company (UBER, 2018). Other companies operating in Brazil, such as the Spanish company Cabify, the Indian company WillGo and the Brazilian companies 99Taxi and Televo, also appeared in this same line of business. In common, all these urban transport companies offer workers a system of work based on "informality" and, more than that, require drivers to have the objective conditions to carry out the activity. In this sense, it is the responsibility of the drivers that operate using the applications to own the main means of production for the activity (car, internet-connected smartphone, fuel, insurance, vehicle maintenance, and eventual expenses with items to please the customer), and we recognize that the transfer of the responsibility over the means of production to the workers is not new. It is possible to observe other productive sectors that have used a similar model where workers should have their means of production to be included in the process, such as the footwear industry, that counts on seamstresses working at home. However, the introduction of the digital platform opens the potential for this model to turn into a productive sector by itself.

We also highlight that it is not only urban transport companies that have adopted similar working relationships. DogHero, for example, has built an online platform so that people can leave their dogs (during a trip, for example) with someone who intends to care for the animal for the period established so that this service pays the temporary caretaker and the company. Chefex allows the hiring, by application, of a chef previously registered by the company to prepare dishes for a small group of people in the residence of the contractor. Sontra Cargo, the company that owns the application that matches transportation companies and truck drivers, allows truckers to find work in any Brazilian state. Another application to highlight is Fitfly, that mediates the service of physical education teachers and clients seeking a personal trainer. This application, unlike Uber, does not charge a percentage of the value received by professionals but monetizes through monthly payments made by the workers in order to be displayed on the platform as service providers (the application also requires quality standards so the teachers can keep using the digital platform). In this direction, there are also applications designed to facilitate the contracting of sexual services. Capital advances in all directions.

At first, uberization may be faced simply as a remedy to cope with unemployment, considering the potential of absorption of labor not included in the formal labor market, and a possibility of greater satisfaction of the consumer market. However, deepening the analysis of labor market trends, capitalist competition, and technological advances, it is possible to see that uberized companies have a competitive advantage in relation to the others - with reduction of advanced constant capital by the capitalist, reduction of shared surplus-value with the State, and the connection between workers' compensation and the 
effective realization of value - which, to a certain extent leads to the perishing of traditional organizations in the areas where they operate and/or their migration to similar forms of operation. Thus, there is a progressive expansion of this kind of labor relations, which facilitates capitalist accumulation while increasing precarious work (without legal protection and increasing the risks of the activity to the worker).

The reflections presented in this article do not exhaust the possibilities of studies seeking to deepen the understanding of the nuances of uberization. As a suggestion for further research, we recommend theoretical-empirical research that uses data from interviews with uberized workers and/or with employers who follow this pattern of (in)formal contract, analyzing the possibilities of resistance and class-consciousness formation, as well as deepening the relationship between uberization and financialization of the economy. Thus, we expect that this study contributes to foster new analyzes that clarify the expansion of the capital, emphasizing the role of science together with the quest for human emancipation (or not) from alienated labor relations. 


\section{REFERENCES}

ABÍLIO, L. C. O make up do trabalho: uma empresa e um milhão de revendedoras de cosméticos. 2018. 307 f. Thesis (Doctor Degree in Sociology) - Universidade Estadual de Campinas, Campinas, 2011.

ANTUNES, R. Os sentidos do trabalho. 3. ed. São Paulo: Boitempo, 2000.

CARELLI, R. L. O caso Uber e o controle por programação: de carona para o Século XIX. In: LEME, A. C. R. P.; RODRIGUES, B. A.; CHAVES JUNIOR, J. E. R. Tecnologias disruptivas e a exploração do trabalho humano. São Paulo: LTr, 2017. p. 130-146.

CHAVES JUNIOR, J. E. R.; MENDES, M. M. B.; OLIVEIRA, M. C. S. Subordinação, dependência e alienidade no trânsito para o capitalismo tecnológico. In: LEME, A. C. R. P.; RODRIGUES, B. A.; CHAVES JUNIOR, J. E. R. Tecnologias disruptivas e a exploração do trabalho humano. São Paulo: LTr, 2017. p. 166-179.

GAULEJAC, V. Gestão como doença social: ideologia, poder gerencialista e fragmentação social. Aparecida: Ideias \& Letras, 2007.

HOWE, J. The rise of crowdsourcing. Wired Magazine, n. 14, p. 1-5, 2006.

LEME, A. C. R. P. Uber e o uso do marketing da economia colaborativa. In: LEME, A. C. R. P.; RODRIGUES, B. A.; CHAVES JUNIOR, J. E. R. Tecnologias disruptivas e a exploração do trabalho humano. São Paulo: LTr, 2017. p. 77-88.

MARX, K. O capital: crítica da economia política. Livro I: o processo de produção do capital. São Paulo: Boitempo, 2013.

MARX, K. O capital: crítica da economia política. Livro II: o processo de circulação do capital. São Paulo: Boitempo, 2014.
MARX, K. O capital: crítica da economia política. Livro III: o processo global da produção capitalista. São Paulo: Boitempo, 2017.

MÉSZÁROS, I. Para além do capital: rumo a uma teoria da transição. São Paulo: Boitempo, 2011.

MÉSZÁROS, I. A teoria da alienação em Marx. São Paulo: Boitempo, 2016.

OLIVEIRA, F. Crítica à razão dualista/O ornitorrinco. São Paulo: Boitempo, 2003.

PASQUALE, F. The black box society: the secret algorithms that control money and information. Cambridge: Harvard University Press, 2015.

SCHEIBER, N. How Uber uses psychological tricks to push its drivers' buttons. 2017. Available at: <https://www.nytimes.com/interactive/2017/04/02/ technology/uber-drivers-psychological-tricks.html>. Accessed on: Jan. 02, 2018.

SIGNES, A. T. O mercado de trabalho no século XXI: on-demand economy, crowdsourcing e outras formas de descentralização produtiva que atomizam o mercado de trabalho. In: LEME, A. C. R. P.; RODRIGUES, B. A.; CHAVES JUNIOR, J. E. R. Tecnologias disruptivas e a exploração do trabalho humano. São Paulo: LTr, 2017. p. x-y.

SLEE, T. Uberização: a nova onda do trabalho precarizado. São Paulo: Elefante, 2017.

SRNICEK, N. Platform capitalism. Cambridge/Malden: Polity, 2017.

UBER. Afinal, qual é a nota mínima exigida pela Uber? 2018. Available at: <https://uberbra.com/afinal-qual-e-a-nota-minima-exigida-pelauber/>. Accessed on: May 02, 2018.

David Silva Franco

ORCID: https://orcid.org/0000-0002-0108-431X

PhD Student and Master in Business Administration from the Federal University of Minas Gerais (UFMG); Professor EBTT at the Federal Institute of Minas Gerais (IFMG), Ribeirão das Neves- MG, Brazil. E-mail: david.franco@ifmg.edu.br

Deise Luiza da Silva Ferraz

ORCID: https://orcid.org/0000-0002-4267-8261

PhD and Master in Business Administration from the Federal University of Rio Grande do Sul (UFRGS); Adjunct Professor at Federal University of Minas Gerais (UFMG), Belo Horizonte- MG, Brazil. E-mail: deiseluiza@face.ufmg.br 